Review

\title{
Evaluating Novel Targets of Ischemia Reperfusion Injury in Pig Models
}

\author{
Andrea Baehr 1,2, Nikolai Klymiuk 1,2 and Christian Kupatt 1,2 \\ 1 Klinikum Rechts der Isar, Internal Medicine I, Technical University of Munich, 81675 Munich, Germany; \\ n.klymiuk@tum.de (N.K.); christian.kupatt@tum.de (C.K.) \\ 2 German Centre for Cardiovascular Research, Munich Heart Alliance, 80802 Munich, Germany \\ * Correspondence: a.baehr@tum.de
}

Received: 10 September 2019; Accepted: 22 September 2019; Published: 25 September 2019

\begin{abstract}
Coronary heart diseases are of high relevance for health care systems in developed countries regarding patient numbers and costs. Disappointingly, the enormous effort put into the development of innovative therapies and the high numbers of clinical studies conducted are counteracted by the low numbers of therapies that become clinically effective. Evidently, pre-clinical research in its present form does not appear informative of the performance of treatments in the clinic and, even more relevant, it appears that there is hardly any consent about how to improve the predictive capacity of pre-clinical experiments. According to the steadily increasing relevance that pig models have gained in biomedical research in the recent past, we anticipate that research in pigs can be highly predictive for ischemia-reperfusion injury (IRI) therapies as well. Thus, we here describe the significance of pig models in IRI, give an overview about recent developments in evaluating such models by clinically relevant methods and present the latest insight into therapies applied to pigs under IRI.
\end{abstract}

Keywords: I/R injury; ischemia reperfusion; pig model; preclinical research; cardiovascular animal model

\section{Introduction}

\subsection{Mechanistic Principles}

Coronary heart disease and consequent myocardial infarction (MI) play a prominent role as health risks, causing heart failure and premature death, particularly in Western societies. Evidently, tremendous research ambitions have been under way during recent decades to alleviate these problems. Despite all progress made in reperfusion therapies, a substantial proportion of heart failure patients (about $50 \%$ ) have ischemic heart disease, most often aggravated by acute ischemic events. There is consent that reperfusion of vessels after acute ischemia may aggravate ischemic tissue injury $[1,2]$. Although the underlying mechanisms are complex, the most essential players have been known for more than a decade [3,4]: reactive oxygen species (ROS) [5], imbalance of $\mathrm{Ca}^{2+}$ homeostasis [6], mitochondrial damage [7] and, consequently, cell death [8]. Specifically, the reperfusion injury salvage kinase (RISK) [9] and survival activating factor enhancement (SAFE) [10] pathways have been explored in more detail as ever more interactions in ROS production became clear [11]. Additional aspects have been identified in the imminent role of mitochondrial damage [12,13] and downstream actors of modified signaling cascades such as the role of transcription factors in altered transcription [14] and the resulting changes in mRNA and miRNA levels [15] have been explored. Some evidence has also been gained that previously unknown players are involved in reperfusion injury: first, the $\mathrm{Ca}^{2+}$ imbalance [16] as well as the insulating effect of myofibroblasts and cardiac fibrosis [17] have been postulated as a causative for reperfusion arrhythmias. Second, autophagy $[18,19]$ as well as the 
innate [20,21] and adaptive [22] immune system appeared major downstream actors of reperfusion injury. It is of note, that any of these effects play an ambiguous role, as they might act in both, a protective as well as in a detrimental manner. Finally, the very downstream event of cell death is not any more imputed to apoptosis [23], but rather to necroptosis, a programmed form of necrosis that appears to play an important role [24].

The complex interplay of so many distinct processes in reperfusion injury (Figure 1) evidently hampers the development of sufficient treatments for myocardial infarction. Almost any axis has been targeted for improving $\mathrm{I} / \mathrm{R}$ injury outcome, but the translation into sufficient clinical application has mostly failed. Multiple approaches using specific pharmacological compounds (reviewed in $[25,26]$ ) as well as numerous cellular transplantation attempts were made (reviewed in [27]). However, the somewhat conflicting outcome led to certain doubts regarding cardioprotective therapies in general [28]. Surprisingly, and in contrast to other holistic approaches of ischemic pre- or post-conditioning, remote ischemic conditioning during the occlusion period but before reperfusion (remote ischemic perconditioning), showed consistent improvement in numerous animals' studies [29] and in a number of clinical trials $[26,30,31]$. Still, the degree of success leaves room for improvement and, thus, there is ongoing ambition to tackle reperfusion injury. However, evaluation of potential targets for improvement of ischemia/reperfusion injury can be challenging. Preclinical large animal models seem a complementary prequisite in the translational process towards clinical application, since rodent models for reperfusion injury not always predict therapeutic efficacy.

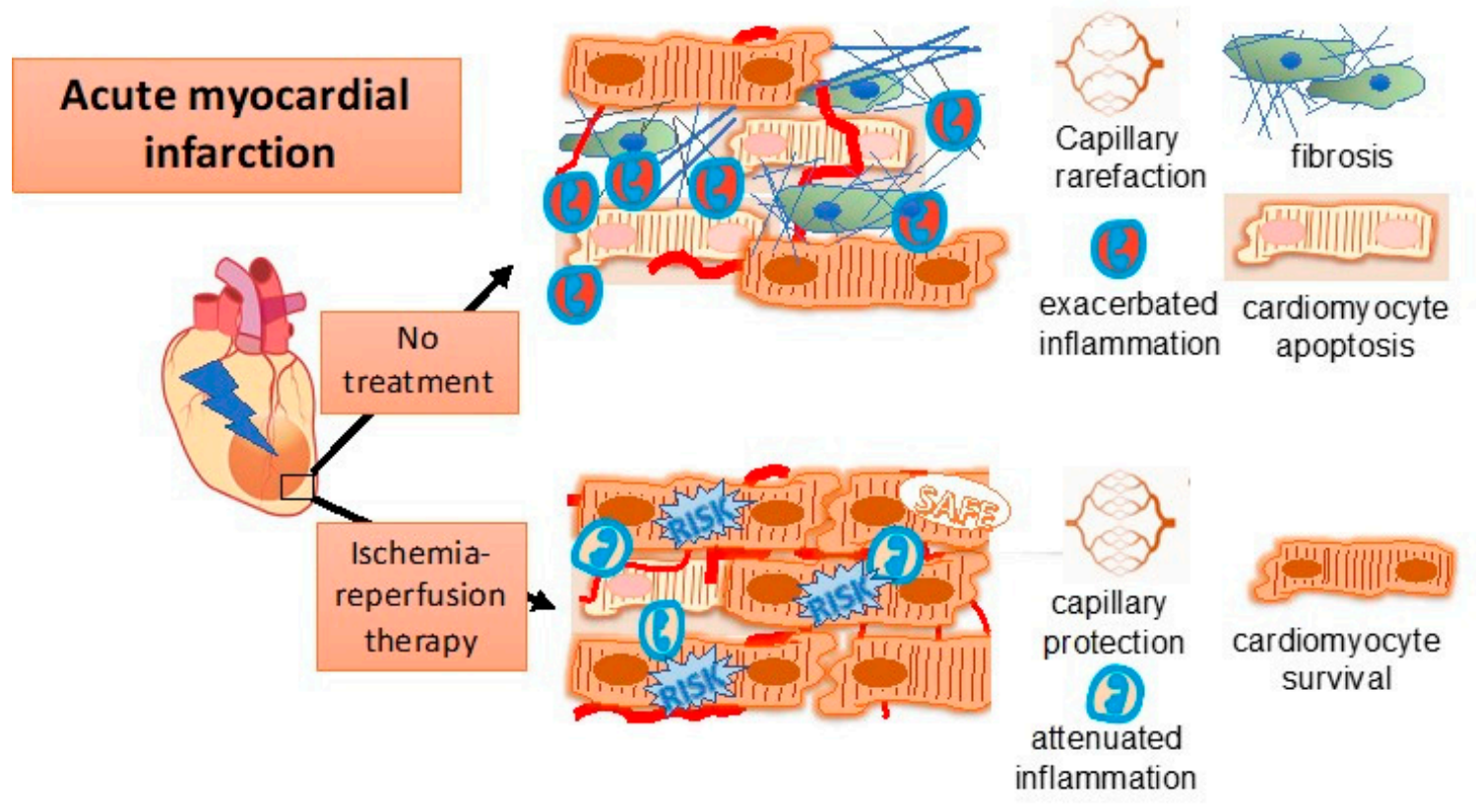

Figure 1. Key players in ischemia reperfusion injury are inflammation, endothelial dysfunction and cardiomyocyte damage.

\subsection{Evaluating Ischemia-Reperfusion Injury in the Pig}

Porcine animal models of myocardial ischemia that allow for the investigation of reperfusion injury have been established for almost three decades [32]. This preference may be explained by two main factors: first, pigs and their hearts come in a size that allows for use of patient-devised catheterization. Second, anatomical and physiological characteristics of the cardiovascular system, e.g., the lack of collaterals or the composition, the heart rate at rest and during exercise, and the post ischemic immune response, are closer to the human counterpart than any other species, except non-human primates. Reproducibility of infarct size normalized to area at risk, e.g., assessed by tetrazolium chloride (TTC) staining [33], and wealth of tissue for post-mortem investigation are further advantages 
of pig heart experiments. The high mortality of pigs after acute ischemia due to a high ventricular arrhythmogenic vulnerability has been a constant problem, which was tamed by the occlusion of the left anterior descending artery (LAD) distal to the first diagonal branch [34]. Finally, prevalent ethical considerations in society allow for the pig's use in preclinical research, as opposed to dogs, cats and primates. First experiments on myocardial infarctions have been conducted in the 1960s and 1970s [35,36] and have been steadily improved and adapted since. Precise protocols are now available for enabling the transfer of models between the labs and for promoting better reference between them $[33,37]$. Equally a driving force are initiatives to align instrumentation and evaluation techniques with clinical standards, including modeling of cardiovascular risk factors such as diabetes [38] and hypercholesterinemia [39].

Significant changes in the field have occurred since the initial histological, structural and immunohistological evaluation of cardiovascular events in the pig [40]. They have been combined with clinic-grade imaging tools, e.g., magnetic resonance imaging (MRI): in a longitudinal study on reperfusion injury, cardiovascular magnetic resonance (CMR) revealed the 2-amplitude course of T2 relaxation in ischemic tissue within the first seven days post reperfusion [41]; in an acute setting, CMR was used to monitor ischemia-induced scar formation [42]; Gadolinium (Gd)-enhanced MRI was used to examine the post-conditional application of cardiosphere-derived cells (CDC) [43]; magnetic resonance imaging was used to determine T1 and T2 mapping in combination with Gd-contrast enhancement, phase-sensitive inversion recovery (LGE), cine-balanced steady-state free precession (bSSFP) and cine displacement encoding with stimulated echoes (DENSE) to analyze ischemia reperfusion injuries [44]. Compressed sensing has been used to further improve 3D multicontrast late enhancement for better identification of low spatiotemporal MR signals [45]. Recently, correlation of CMR-based elastography to mechanical testing of myocardial stiffness has been demonstrated also in the pig [46,47].

Apart from classical approaches for assessing immediate heart function, there is ambition in identifying reliable prognostic biomarkers for post ischemic patient cohorts. As an example, the volume of neutrophils appeared to be increased in post-MI patients as well as in MI pig models [48]. Upon systematic post-experimental asservation, the pig evidently facilitates insight at a cellular or molecular level. Preparation of cardiac tissue for 2D or 3D examination of heart anatomy has been described in a standardized way [49]. Preparation of tissue for confocal microscopy has been documented in an automated procedure [50]. Even 3D spatiotemporal dynamics has been explored in the pig heart by ultrasound-based strain imaging [51]. Evidently, and although annotation of the porcine genome is still significantly behind the status of human (or mouse), innovative next generation tools suggest the implementation of "-omics", holistic genomic, transcriptomic or proteomic tools [52], with a particular emphasis not only on protein abundance, but also on their activation status [53]. Finally, in the age of artificial intelligence, the mathematical modelling and cumulative interpretation of raw data from different studies is gaining traction [54]. Protocols and endpoints have been established which allow correlation of preclinical outcome with future clinical examinations $[55,56]$.

\section{Promising Targets in I/R Injury}

Targets for encountering I/R injury range from adaptations to hemodynamic parameters such as ischemic pre- and post-conditioning, microvascular protection [57], post ischemic inflammation [58], physical interventions (oxygen saturation, pressure or temperature, mechanical interventions) to pharmacological treatment, cell and exosome therapies [59] as well as bio-therapeutics that target specific regulatory cascades. Finally, also the combination of two or more of these approaches have been investigated in preclinical pig models.

\subsection{Conditioning: Role of the RISK, SAFE and NO Pathways}

The finding that manipulating or conditioning the immediate reperfusion process is feasible [1], has triggered numerous studies for improving the outcome of MI. The I/R injury treatment by remote ischemic perconditioning has been found to protect the porcine heart $[60,61]$, but has only recently 
failed to demonstrate reduction of cardiac death or hospitalization for heart failure at 12 months in the Condi2-ERIC-PPCI trial [60]. Combining ischemic post-conditioning with administration of liraglutide, there is a tendency towards smaller infarcts, albeit non-significant [62]. In neonatal pigs, pre-conditioning appeared useful only in combination with continuous application of glucose and insulin [63]. As stated before, the RISK pathway, i.e. activation of PI3K-AKT- and MEK1-ERK1/2 [9], and the SAFE pathway, requiring activation of Stat3 [64], are potentially involved in reducing the impact of ischemia and reperfusion on the tissue [65]. Preconditioning with antagonists of the RISK and SAFE pathways revealed that only the latter is essential for the protective effect [65]. A study of remote ischemic pre- and perconditioning in a pig model of MI demonstrated activation of the PI3K-AKT pathway only by preconditioning the animal prior to MI but not by applying remote ischemic perconditioning during MI [66]. A transcriptome profile of pre-conditioned pig hearts supported the assumption that the activation status of STAT3 is indispensable in the stimulation of the SAFE pathway $[67,68]$, as well as in remote perconditioning of ischemic pig hearts [69], but a specific stimulation of this pathway has not been tested yet in this species.

Trials for reducing infarct size have also included the application of bloodless reperfusion solutions containing oxygen carriers with and without additives such as glucose. However, no beneficial effect of these procedures could be found so far [70], although the delay of re-exposure of the myocardium to inflammation conveying blood components is attractive. High arterial oxygen reperfusion might, on the other hand, also cause excessive oxidative stress und as such aggravate I/R injury. Indeed, Abdel-Rahman et al. [71] could show that hypoxic reoxygenation in the early phase of reperfusion protects post ischemic myocardial function.

Inhibition of reperfusion induced thrombin has shown a beneficial effect on cardiac function after myocardial ischemia [72]. Carbon monoxide application can improve the energy status of post ischemic porcine hearts by increasing adenosine triphosphate (ATP) production. This leads to a decrease in edema formation and apoptosis, thus acting as a cardioprotective agent [73]. Similarly, preconditioning by nitric oxide (NO) application has improved capillary reperfusion by modifying myocardial oxygen consumption during reperfusion [74]. A longer lasting NO increasing intervention was performed by retroinfusion of the liposome-encoded active form of endothelial nitric oxide synthase (eNOS), which sufficed to decrease neutrophil invasion and infarct size [75]. In 2007, Eiferman et al. [76] could already show that systemic glucose-insulin-potassium infusion can improve myocardial recovery during reperfusion. This finding is in contrast to a previously mentioned study where glucose-insulin application had no significant effect on cardioprotection [63]. Importantly, however, the latter study focused on neonatal pigs in which the heart relies almost exclusively on carbohydrate metabolism. However, a metaanalysis of Zhao et al. of 23864 patients detected no benefit of glucose-insulin-potassium infusion in 11 randomized controlled trials [77].

\subsection{Pharmacological Intervention}

Pharmacological pre- and postconditioning has been investigated in regular intervals over the past decades. At times, different intervention targets came into fashion and fell out of vogue again. $\mathrm{Na}^{+} / \mathrm{H}^{+}$ exchange inhibitors seem to be a representative example. They appeared protective in $\mathrm{I} / \mathrm{R}$ injury by preventing $\mathrm{Na}^{+}$overload [78-80]. In combination with controlled reperfusion using leukocyte-depleted blood, Fedalen et al. [81] could confirm the protective effect of $\mathrm{Na}^{+} / \mathrm{H}^{+}$exchange inhibitors. In own experiments, the combination of Cariporide and the antioxidant glutathione (GSH), but not the singular agents, attenuated porcine ischemia-reperfusion injury [82]. Consistently, no clear-cut benefit could be shown for Cariporide in the GUARDIAN trial of acute coronary syndrome patients [83].

Only recently, repurposing of pharmacological agents gained attraction, which is particularly the case for antihypertensive treatments. Among them, pre-treatment of a porcine MI model with eprosartan, showed improvement in regional cardiac function [84]. Similar improvement on hemodynamic parameters was obtained in ventricular fibrillation models upon treatment with nicorandil [85] and enalapril [86]. The application of diazoxide, a potassium channel opener of the 
mitochondria, also resulted in reduced MI damage [87]. It is, however, not known whether the drug acts indirectly by inducing vasodilation via relaxation of smooth muscle cells, or by altering osmolality in cardiomyocytes directly.

Further approaches targeting mitochondrial dysfunction were also mainly based on established drugs: TRO40303, a stabilizer of mitochondrial membrane permeability showed only very mild protection in a pig model of MI [88], and did not prove protective in a clinical trial of ST-elevation myocardial infarction (STEMI) patients [89]. Cyclosporine, preventing opening of the mitochondrial transition pore via cyclophiline [7], seemed to reduce infarct size (hyperenhancement on MRI) in a small patient cohort with acute MI [90], but failed to replicate the result in the larger Circus trial [91]. Ironically, in a previous porcine study, cyclosporine did not provide cardioprotection either [92]. In the preclinical arena, though, another stabilizer of the mitochondrial membrane, TVP1022, a modified version of the anti-Parkinson-drug rasagiline, prevented scar formation and improved cardiac function in MI [93]. No patient data are available as of yet.

On a more global level, the manipulation of the master regulator transcription factor Egr-1 that influences the key players of $\mathrm{I} / \mathrm{R}$ injury, inflammation and apoptosis, leads to improved cardiac function after I/R [94]. Ivabradine, an inhibitor of cAMP-gated $\mathrm{I}_{f}$ channels, has been investigated intensively in the past and revealed multiple cardioprotective effects [95], but did not show superiority to standard treatment in larger patient cohorts with myocardial infarction [96]. A similar fate was experienced by metformin $[97,98]$ and carperitide [99]. In pigs, rapamycin, a mitosis blocker widely used as immunosuppressant and anti-restenosis drug on stents, surprisingly decreased cardiac function and induced myocardial necrosis [100]. Another multiple effective compound, however, deltorphin, an agonist of the delta opioid receptor, very recently prevented arrhythmia upon reperfusion in a porcine working heart model [101].

\subsection{Biomimetics}

A further trend in pharmacological conditioning is the increase in using biomimetic compounds, This is intriguingly illustrated by the case of anti-inflammatory or anti-oxidative approaches for MI in the pig [102-105], but has given way to biomimetics in the recent past, e.g., the unsuccessful clinical trial with glucocorticoids [106], which in preclinical rat, cat, rabbit and dog models has shown less devastating results (for review see [107]). Post ischemic sterile inflammation, with its orchestrated upregulation of cytokines and chemokines attracting neutrophils and monocytes/macrophages, is an often targeted process in ischemia-reperfusion treatment (for review see [58]). Although inhibition of endothelial activation with an anti-CD18 antibody (IB4) combined with NF Kappa B decoy oligonucleotides reduced early ischemia reperfusion injury in pigs [108], no singular agent was clinically successful to date, most likely due to the janus-faced nature of inflammatory cells, providing damage and repair at the same time. Novel approaches, such as administration of OPN-305, an anti-inflammatory clinical grade humanized anti-TLR2 antibody, led to improved cardiac function, albeit only at relatively high concentrations [104]. Moreover, application of the NLRP3-inflammasome inhibitor MCC950, in effect preventing formation of interleukin $1 \beta$, a pro-inflammatory cytokine initiating and maintaining post ischemic sterile inflammation, reduced infarct size and improved myocardial function after $75 \mathrm{~min}$ of LAD occlusion in pigs [109]. Using a gene therapeutic approach, cardioprotection by adeno-associated virus (AAV)-based hemoxygenase 1 (HO-1) overexpression decreased infarct size and post ischemic loss of function, apparently by reducing post ischemic neutrophil influx in pig hearts to a similar extent as ubiquitous HO-1 cardioprotection [110].

A cardiomyocyte-targeted approach such as AAV-mediated overexpression of myocardin related transcription factor A (MRTF-A), which induces expression of myocytic as well as angiogenic genes, improves ischemic myocardial tissue in a pig model of hibernating myocardium [111] and acute I/R. Interestingly, MRTF-A has been essential for maintenance of cardiomyocyte differentiation [112], similar to an upstream peptide of the MRTF-A/SRF pathway, thymosin beta 4 (TB4), which promotes differentiation towards cardiomyocytes [113]. Consistently, administration of either recombinant 
TB4 [114], or TB4 encoding plasmid or AAV-delivered TB4 [39] all proved cardioprotective. Moreover, AAV gene transfer of PR39, a pro-angiogenic protein which induces the transcription factor HIF1alpha, in turn attenuates $\mathrm{MI}$ in pigs [115]. In addition, a silencing oligonucleotide against the promoter region of EGR1 was used in a pig model of MI [94], whereas the application of miRNAs revealed that also post-transcriptional regulation at RNA level might be valuable in preventing reperfusion damage [116]. Finally, an inhibitor of microRNA92a (LNA-92a) exerted pleiotropic effects on cardiomyocyte survival, attenuation of neutrophil influx as well as capillary preservation [117].

Another essential field of intervention for I/R injury appears to be the immediate stabilization of damaged tissue. Mitsugumin53 (MG53), a proposed stabilizer of membranes, was used to prevent I/R injury $[118,119]$ and a first-in-pig study had added evidence [120], but since then no further pre-clinical examination has been presented. Another approach focused on a steroid component of membranes, cholesteryl esters: again, stabilization of membranes improved IRI outcome [121]. A similar attempt was followed with rotigaptide, a hexapeptide that enhances electrical coupling of cardiomyocytes by modulating connexin activity [122]. Very differently, tissue damage was successfully prevented by apheresis of C-reactive protein from the circulation [123].

\subsection{Cellular Treatments}

Longterm cell supplementation for lost or dysfunctional parenchymal or vascular cells is not an easy task in the heart. Despite the mixed results of clinical study metaanalyses $[125,126]$, intramyocardial injection of $1 \times 10^{7}$ bone marrow derived cells improved LV diameters and EF at 3 months after MI [127], similar to bone marrow mesenchymal stem cell transplantation induced glucose transporter genes as well as mTOR signaling in 4-week-old porcine infarct areas [128]. Beyond bone-marrow cells, cardiac-derived cells (CDC) were applied either by intracoronary infusion [129-131] or by intra-myocardial injection [132] in pig hearts, preventing loss of cardiac function post MI and improving myocardial perfusion [131]. The Scipio trial, a clinical phase I study, showed encouraging results [133], the Caduceus trial reported an increase in viable myocardium in the infarct zone of 17 MI patients [134].

Further advancing the field and simplifying the approach are exosomes, as small (30-100 nm) vesicles derived from luminal membranes of multivesicular bodies that are capable of carrying protein, mRNA or microRNA cargo [135]. CDC-derived exosomes, applied either by intracoronary infusion or by intramyocardial injection, sufficed to prevent adverse remodeling in pig hearts [136,137]. The latter study found that fibroblast-derived exosomes did not result in the same benefit unless they were spiked with miR-181b miRNA. Other factors isolated from plasma-derived exosomes include heat shock protein 70 (Hsp70) and pregnancy-associated plasma protein-A (PAPP-A) [59].

For providing a supportive environment of endogenous or exogenously applied cells, extracellular matrix hydrogel was injected into the myocardium two weeks post MI and resulted in an improved endocardial muscle content with reduced fibrotic tissue [138]. This material itself did not provide improvement of adverse cardiac remodeling in the heart in patients, but is potentially useful as a therapeutic niche for further cardiac cell seeding, given a favorable safety profile [139]. Furthermore, the extracellular matrix protein agrin contains potential for cardiac regeneration in mice [140], and is currently assessed for its potential to attenuate ischemia-reperfusion injury in pigs (E. Tzahor, personal communication).

Closing the gap to mature, functional cardiomyocytes, human embryonic stem cell derived cardiomyocytes were engrafting in the infarcted apex of pig hearts, mounting a trend towards more wall-thickening at 4 weeks post-MI. On the other hand, a substantial number of, at times fatal, ventricular tachycardias was detected in between [141]. Engineered heart tissue derived from human induced pluripotent stem cells (iPSCs), which beneficially affected cardiac remodeling [142] and did not spark ventricular arrhythmias in a guinea pig cryo-injury model [143], are currently tested in porcine models.

Conceptually, many cell-therapeutic approaches foresee a xenogeneic situation and complex control of immune rejection in pigs, triggering the use of immunocompromised pigs, e.g., by identification of 
naturally occurring mutations or by genetic engineering [144]. Most of these immunodeficient models suffer from defects in ILR2G, RAG1, RAG2 or Artemis, requiring suitable housing under specific pathogen free (SPF) conditions [145]. We have recently developed an alternative pig model that proved immune-deficient due to the transgenic expression of the T-cell activation inhibitor LEA29Y [146], which upon maintenance in an SPF facility [147] has shown effective natural reproduction (unpublished data). Such animals might be appropriate for testing cellular transplants in $\mathrm{I} / \mathrm{R}$ injury.

\section{Summary \& Outlook}

The intensive research that has been done on pre-clinical evaluation of treatment options for myocardial infarction in pigs in the recent past illustrates the relevance of this species in bridging the gap from basic research to clinical application. Key areas of development are (1) modifiers of post ischemic inflammation (inflammasome inhibitors, cytokine/chemokine inhibitors), (2) stabilizers of mitochondrial and metabolic functions of cardiomyocytes and (3) protective agents for microcirculatory structure and function. Several principles such as enhancing the MRTF-A/SRF pathway, affect more than one of these processes [111]. Still, many studies described here are not fully comparable in detail, precluding a ranking of $\mathrm{I} / \mathrm{R}$ injury targets in a defined manner. As shown in Table 1 , a variety of pharmacological agents have been assessed in pigs, which in most cases matched available clinical data. Nevertheless, preclinical large animal studies do not always accurately predict clinical studies, e.g., remote ischemic conditioning and anti-inflammatory therapies. A heterogeneity issue in larger clinical cohorts with regard to risk factors, uncontrolled ischemia length in patients, heterogeneity of patient age, training state, pharmacotherapies and co-morbidities is notoriously hard to model [148,149], although pigs of different ages, with one or more cardiovascular risk factors (diabetes, hyperlipidemia, hypertension) $[38,150,151]$, are available. However, application of a standardized, good manufacturing practice (GMP) grade, biological agent is more difficult than in small animals. Moreover, the specificity of the agent may vary from species to species, e.g., in the field of non-coding RNAs or cell-based treatments for $\mathrm{I} / \mathrm{R}$ injury.

Table 1. Pharmacological agents assessed in porcine/human studies of ischemia-reperfusion.

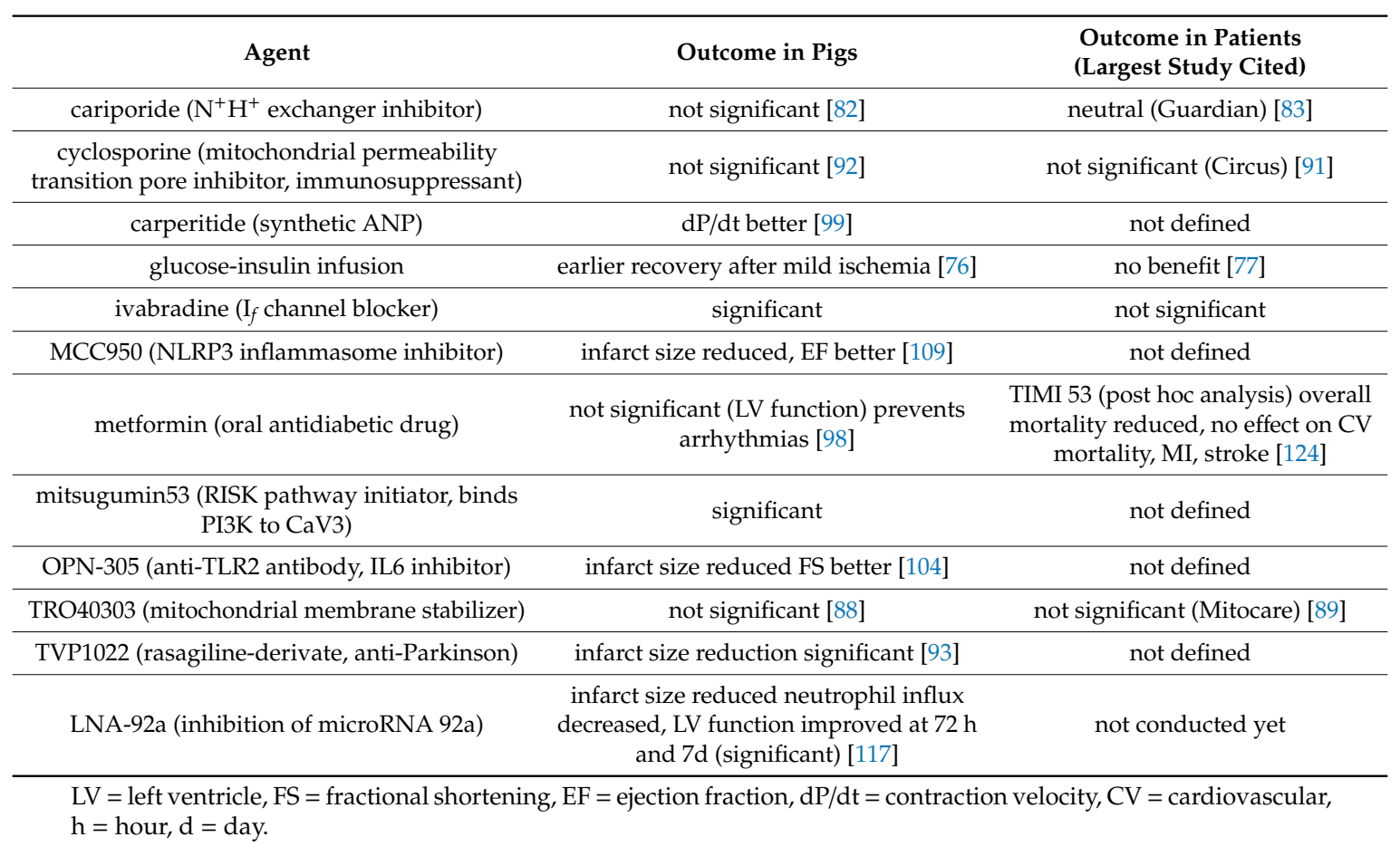


In summary, the adaptation of novel imaging technologies and the availability of genetically modified pig models are cornerstones in advancing pig pre-clinical models for testing I/R injury treatments. It is safe to assume that application routes, dosages and timing of novel therapeutics can be elaborated in pig models which are closely resembling clinical scenarios. In addition, porcine studies may aid in elucidating mechanisms of action as well as efficacy of therapeutic agents, which are evolving from basic research or clinical studies as attractive in treating ischemia and reperfusion injury.

Author Contributions: A.B. and N.K. conceptualized and prepared the original draft; C.K. conceptualized, reviewed and edited the draft.

Funding: This research was funded by the German Research Foundation (Deutsche Forschungsgemeinschaft, DFG) grant number TRR 127 and the DZHK (German Centre for Cardiovascular Research), Large Animal Platform.

Conflicts of Interest: The authors declare no conflict of interest.

\section{References}

1. Hausenloy, D.J.; Yellon, D.M. Myocardial ischemia-reperfusion injury: a neglected therapeutic target. J. Clin. Investig. 2013, 123, 92-100. [CrossRef] [PubMed]

2. Jennings, R.B. Historical perspective on the pathology of myocardial ischemia/reperfusion injury. Circ. Res. 2013, 113, 428-438. [CrossRef] [PubMed]

3. Hausenloy, D.J.; Yellon, D.M. Preconditioning and postconditioning: united at reperfusion. Pharm. Ther. 2007, 116, 173-191. [CrossRef]

4. Wu, M.Y.; Yiang, G.T.; Liao, W.T.; Tsai, A.P.; Cheng, Y.L.; Cheng, P.W.; Li, C.Y.; Li, C.J. Current Mechanistic Concepts in Ischemia and Reperfusion Injury. Cell Physiol. Biochem. 2018, 46, 1650-1667. [CrossRef]

5. Horstkotte, J.; Perisic, T.; Schneider, M.; Lange, P.; Schroeder, M.; Kiermayer, C.; Hinkel, R.; Ziegler, T.; Mandal, P.K.; David, R.; et al. Mitochondrial thioredoxin reductase is essential for early postischemic myocardial protection. Circulation 2011, 124, 2892-2902. [CrossRef] [PubMed]

6. Luongo, T.S.; Lambert, J.P.; Gross, P.; Nwokedi, M.; Lombardi, A.A.; Shanmughapriya, S.; Carpenter, A.C.; Kolmetzky, D.; Gao, E.; van Berlo, J.H.; et al. The mitochondrial $\mathrm{Na}(+) / \mathrm{Ca}(2+)$ exchanger is essential for $\mathrm{Ca}(2+)$ homeostasis and viability. Nature 2017, 545, 93-97. [CrossRef] [PubMed]

7. Baines, C.P.; Kaiser, R.A.; Purcell, N.H.; Blair, N.S.; Osinska, H.; Hambleton, M.A.; Brunskill, E.W.; Sayen, M.R.; Gottlieb, R.A.; Dorn, G.W.; et al. Loss of cyclophilin D reveals a critical role for mitochondrial permeability transition in cell death. Nature 2005, 434, 658-662. [CrossRef] [PubMed]

8. Del Re, D.P.; Amgalan, D.; Linkermann, A.; Liu, Q.; Kitsis, R.N. Fundamental Mechanisms of Regulated Cell Death and Implications for Heart Disease. Physiol. Rev. 2019, 99, 1765-1817. [CrossRef] [PubMed]

9. Rossello, X.; Yellon, D.M. The RISK pathway and beyond. Basic. Res. Cardiol. 2018, 113, 2. [CrossRef] [PubMed]

10. Hadebe, N.; Cour, M.; Lecour, S. The SAFE pathway for cardioprotection: Is this a promising target? Basic. Res. Cardiol. 2018, 113, 9. [CrossRef]

11. Granger, D.N.; Kvietys, P.R. Reperfusion injury and reactive oxygen species: The evolution of a concept. Redox. Biol. 2015, 6, 524-551. [CrossRef] [PubMed]

12. Niemann, B.; Schwarzer, M.; Rohrbach, S. Heart and Mitochondria: Pathophysiology and Implications for Cardiac Surgeons. Thorac. Cardiovasc. Surg. 2018, 66, 11-19. [PubMed]

13. Chang, M.Y.; Huang, T.T.; Chen, C.H.; Cheng, B.; Hwang, S.M.; Hsieh, P.C. Injection of Human Cord Blood Cells With Hyaluronan Improves Postinfarction Cardiac Repair in Pigs. Stem Cells Transl. Med. 2016, 5, 56-66. [CrossRef] [PubMed]

14. Jakobs, P.; Serbulea, V.; Leitinger, N.; Eckers, A.; Haendeler, J. Nuclear Factor (Erythroid-Derived 2)-Like 2 and Thioredoxin-1 in Atherosclerosis and Ischemia/Reperfusion Injury in the Heart. Antioxid. Redox. Signal. 2017, 26, 630-644. [CrossRef] [PubMed]

15. Gottlieb, R.A.; Pourpirali, S. Lost in translation: miRNAs and mRNAs in ischemic preconditioning and ischemia/reperfusion injury. J. Mol. Cell Cardiol. 2016, 95, 70-77. [CrossRef] [PubMed]

16. Van der Weg, K.; Prinzen, F.W.; Gorgels, A.P. Editor's Choice- Reperfusion cardiac arrhythmias and their relation to reperfusion-induced cell death. Eur. Heart J. Acute Cardiovasc. Care 2019, 8, 142-152. [CrossRef] [PubMed] 
17. De Bakker, J.M.T. Do Myofibroblasts Represent a Hidden Factor for Impaired Conduction and Tachyarrhythmia in Post-Myocardial Infarction? Jacc Clin. Electrophysiol. 2017, 3, 715-717. [CrossRef] [PubMed]

18. Ghavami, S.; Gupta, S.; Ambrose, E.; Hnatowich, M.; Freed, D.H.; Dixon, I.M. Autophagy and heart disease: implications for cardiac ischemia-reperfusion damage. Curr. Mol. Med. 2014, 14, 616-629. [CrossRef] [PubMed]

19. Ma, S.; Wang, Y.; Chen, Y.; Cao, F. The role of the autophagy in myocardial ischemia/reperfusion injury. Biochim. Biophys. Acta 2015, 1852, 271-276. [CrossRef]

20. Liu, J.; Wang, H.; Li, J. Inflammation and Inflammatory Cells in Myocardial Infarction and Reperfusion Injury: A Double-Edged Sword. Clin. Med. Insights Cardiol. 2016, 10, 79-84. [CrossRef]

21. De Couto, G.; Liu, W.; Tseliou, E.; Sun, B.; Makkar, N.; Kanazawa, H.; Arditi, M.; Marban, E. Macrophages mediate cardioprotective cellular postconditioning in acute myocardial infarction. J. Clin. Investig. 2015, 125, 3147-3162. [CrossRef]

22. Boag, S.E.; Andreano, E.; Spyridopoulos, I. Lymphocyte Communication in Myocardial Ischemia/Reperfusion Injury. Antioxid. Redox Signal. 2017, 26, 660-675. [CrossRef] [PubMed]

23. Kossmehl, P.; Kurth, E.; Faramarzi, S.; Habighorst, B.; Shakibaei, M.; Wehland, M.; Kreutz, R.; Infanger, M.; AH, J.D.; Grosse, J.; et al. Mechanisms of apoptosis after ischemia and reperfusion: role of the renin-angiotensin system. Apoptosis 2006, 11, 347-358. [CrossRef] [PubMed]

24. Linkermann, A.; Hackl, M.J.; Kunzendorf, U.; Walczak, H.; Krautwald, S.; Jevnikar, A.M. Necroptosis in immunity and ischemia-reperfusion injury. Am. J. Transpl. 2013, 13, 2797-2804. [CrossRef] [PubMed]

25. Hausenloy, D.J.; Garcia-Dorado, D.; Botker, H.E.; Davidson, S.M.; Downey, J.; Engel, F.B.; Jennings, R.; Lecour, S.; Leor, J.; Madonna, R.; et al. Novel targets and future strategies for acute cardioprotection: Position Paper of the European Society of Cardiology Working Group on Cellular Biology of the Heart. Cardiovasc. Res. 2017, 113, 564-585. [CrossRef] [PubMed]

26. Bulluck, H.; Yellon, D.M.; Hausenloy, D.J. Reducing myocardial infarct size: challenges and future opportunities. Heart 2016, 102, 341-348. [CrossRef] [PubMed]

27. Madonna, R.; Van Laake, L.W.; Davidson, S.M.; Engel, F.B.; Hausenloy, D.J.; Lecour, S.; Leor, J.; Perrino, C.; Schulz, R.; Ytrehus, K.; et al. Position Paper of the European Society of Cardiology Working Group Cellular Biology of the Heart: cell-based therapies for myocardial repair and regeneration in ischemic heart disease and heart failure. Eur. Heart J. 2016, 37, 1789-1798. [CrossRef] [PubMed]

28. Lefer, D.J.; Marban, E. Is Cardioprotection Dead? Circulation 2017, 136, 98-109. [CrossRef] [PubMed]

29. Bromage, D.I.; Pickard, J.M.; Rossello, X.; Ziff, O.J.; Burke, N.; Yellon, D.M.; Davidson, S.M. Remote ischaemic conditioning reduces infarct size in animal in vivo models of ischaemia-reperfusion injury: a systematic review and meta-analysis. Cardiovasc. Res. 2017, 113, 288-297. [PubMed]

30. Schmidt, M.R.; Rasmussen, M.E.; Botker, H.E. Remote Ischemic Conditioning for Patients With STEMI. J. Cardiovasc. Pharmacol. Ther. 2017, 22, 302-309. [CrossRef] [PubMed]

31. Botker, H.E.; Lassen, T.R.; Jespersen, N.R. Clinical translation of myocardial conditioning. Am. J. Physiol. Heart Circ. Physiol. 2018, 314, H1225-H1252. [CrossRef] [PubMed]

32. Juneau, C.F.; Ito, B.R.; del Balzo, U.; Engler, R.L. Severe neutrophil depletion by leucocyte filters or cytotoxic drug does not improve recovery of contractile function in stunned porcine myocardium. Cardiovasc. Res. 1993, 27, 720-727. [CrossRef] [PubMed]

33. Bøtker, H.E.; Hausenloy, D.; Andreadou, I.; Antonucci, S.; Boengler, K.; Davidson, S.M.; Deshwal, S.; Devaux, Y.; Di Lisa, F.; Di Sante, M.; et al. Practical guidelines for rigor and reproducibility in preclinical and clinical studies on cardioprotection. Basic. Res. Cardiol. 2018, 113, 39. [CrossRef] [PubMed]

34. Hanes, D.W.; Wong, M.L.; Jenny Chang, C.W.; Humphrey, S.; Grayson, J.K.; Boyd, W.D.; Griffiths, L.G. Embolization of the first diagonal branch of the left anterior descending coronary artery as a porcine model of chronic trans-mural myocardial infarction. J. Transl. Med. 2015, 13, 187. [CrossRef] [PubMed]

35. Arora, R.B.; Sivappa, D.S. Ectopic ventricular rhythms and myocardial infarction in the domestic pig and their response to nialamide, a monoamine oxidase inhibitor. Br. J. Pharm. Chemother. 1962, 19, 394-404. [CrossRef] [PubMed]

36. Myers, M.B.; Cherry, G. Ventricular fibrillation area thresholds in the dog and pig. Determined by a new experimental model for the production of myocardial infarction. J. Thorac. Cardiovasc. Surg. 1970, 59, 401-412. [PubMed] 
37. McCall, F.C.; Telukuntla, K.S.; Karantalis, V.; Suncion, V.Y.; Heldman, A.W.; Mushtaq, M.; Williams, A.R.; Hare, J.M. Myocardial infarction and intramyocardial injection models in swine. Nat. Protoc. 2012, 7, 1479-1496. [CrossRef] [PubMed]

38. Hinkel, R.; Howe, A.; Renner, S.; Ng, J.; Lee, S.; Klett, K.; Kaczmarek, V.; Moretti, A.; Laugwitz, K.L.; Skroblin, P.; et al. Diabetes Mellitus-Induced Microvascular Destabilization in the Myocardium. J. Am. Coll. Cardiol. 2017, 69, 131-143. [CrossRef] [PubMed]

39. Ziegler, T.; Bahr, A.; Howe, A.; Klett, K.; Husada, W.; Weber, C.; Laugwitz, K.L.; Kupatt, C.; Hinkel, R. Tbeta4 Increases Neovascularization and Cardiac Function in Chronic Myocardial Ischemia of Normo- and Hypercholesterolemic Pigs. Mol. Ther. 2018, 26, 1706-1714. [CrossRef]

40. Frederiks, W.M.; Tukkie, R.; Grundeman, P.F.; Hoebe, C.; Schellens, J.P. Combined enzyme histochemical and ultrastructural study on cryostat sections of pig heart to detect early reperfusion damage after ischaemia. J. Pathol. 1995, 175, 339-348. [CrossRef]

41. Fernandez-Jimenez, R.; Sanchez-Gonzalez, J.; Aguero, J.; Garcia-Prieto, J.; Lopez-Martin, G.J.; Garcia-Ruiz, J.M.; Molina-Iracheta, A.; Rossello, X.; Fernandez-Friera, L.; Pizarro, G.; et al. Myocardial edema after ischemia/reperfusion is not stable and follows a bimodal pattern: imaging and histological tissue characterization. J. Am. Coll. Cardiol. 2015, 65, 315-323. [CrossRef] [PubMed]

42. Guzman-Martinez, G.; Fernandez-Friera, L.; Moral, S.; Shapiro, S.; Bates, D.; Hajjar, R.; Garcia, M.J.; Fuster, V.; Sanz, J. Intra-scar perfusion heterogeneity by cardiac magnetic resonance in a porcine model of non-reperfused myocardial infarction. Int. J. Cardiol. 2014, 176, 1288-1289. [CrossRef] [PubMed]

43. Malliaras, K.; Smith, R.R.; Kanazawa, H.; Yee, K.; Seinfeld, J.; Tseliou, E.; Dawkins, J.F.; Kreke, M.; Cheng, K.; Luthringer, D.; et al. Validation of contrast-enhanced magnetic resonance imaging to monitor regenerative efficacy after cell therapy in a porcine model of convalescent myocardial infarction. Circulation 2013, 128, 2764-2775. [CrossRef] [PubMed]

44. Lopez, D.; Pan, J.A.; Pollak, P.M.; Clarke, S.; Kramer, C.M.; Yeager, M.; Salerno, M. Multiparametric CMR imaging of infarct remodeling in a percutaneous reperfused Yucatan mini-pig model. Nmr. Biomed. 2017, 30. [CrossRef] [PubMed]

45. Zhang, L.; Athavale, P.; Pop, M.; Wright, G.A. Multicontrast reconstruction using compressed sensing with low rank and spatially varying edge-preserving constraints for high-resolution MR characterization of myocardial infarction. Magn. Reson. Med. 2017, 78, 598-610. [CrossRef] [PubMed]

46. Mazumder, R.; Schroeder, S.; Mo, X.; Clymer, B.D.; White, R.D.; Kolipaka, A. In vivo quantification of myocardial stiffness in hypertensive porcine hearts using MR elastography. J. Magn. Reson. Imaging 2017, 45, 813-820. [CrossRef] [PubMed]

47. Mazumder, R.; Schroeder, S.; Mo, X.; Litsky, A.S.; Clymer, B.D.; White, R.D.; Kolipaka, A. In vivo magnetic resonance elastography to estimate left ventricular stiffness in a myocardial infarction induced porcine model. J. Magn. Reson. Imaging 2017, 45, 1024-1033. [CrossRef]

48. Van Hout, G.P.; van Solinge, W.W.; Gijsberts, C.M.; Teuben, M.P.; Leliefeld, P.H.; Heeres, M.; Nijhoff, F.; de Jong, S.; Bosch, L.; de Jager, S.C.; et al. Elevated mean neutrophil volume represents altered neutrophil composition and reflects damage after myocardial infarction. Basic. Res. Cardiol. 2015, 110, 58. [CrossRef]

49. Van den Broek, H.T.; De Jong, L.; Doevendans, P.A.; Chamuleau, S.A.J.; Van Slochteren, F.J.; Van Es, R. 3D Whole-heart Myocardial Tissue Analysis. J. Vis. Exp. 2017. [CrossRef]

50. Gkontra, P.; Norton, K.A.; Zak, M.M.; Clemente, C.; Aguero, J.; Ibanez, B.; Santos, A.; Popel, A.S.; Arroyo, A.G. Deciphering microvascular changes after myocardial infarction through $3 \mathrm{D}$ fully automated image analysis. Sci. Rep. 2018, 8, 1854. [CrossRef]

51. Christoph, J.; Chebbok, M.; Richter, C.; Schroder-Schetelig, J.; Bittihn, P.; Stein, S.; Uzelac, I.; Fenton, F.H.; Hasenfuss, G.; Gilmour, R.F.; et al. Electromechanical vortex filaments during cardiac fibrillation. Nature 2018, 555, 667-672. [CrossRef] [PubMed]

52. Chilukoti, R.K.; Lendeckel, J.; Darm, K.; Bukowska, A.; Goette, A.; Suhling, M.; Utpatel, K.; Peters, B.; Homuth, G.; Volker, U.; et al. Integration of “omics" techniques: Dronedarone affects cardiac remodeling in the infarction border zone. Exp. Biol. Med. (Maywood) 2018, 243, 895-910. [CrossRef] [PubMed]

53. Ledee, D.; Kang, M.A.; Kajimoto, M.; Purvine, S.; Brewer, H.; Pasa-Tolic, L.; Portman, M.A. Quantitative cardiac phosphoproteomics profiling during ischemia-reperfusion in an immature swine model. Am. J. Physiol. Heart Circ. Physiol. 2017, 313, H125-H137. [CrossRef] [PubMed] 
54. Qi, K.; Li, L.; Li, X.; Zhao, J.; Wang, Y.; You, S.; Hu, F.; Zhang, H.; Cheng, Y.; Kang, S.; et al. Cardiac microvascular barrier function mediates the protection of Tongxinluo against myocardial ischemia/reperfusion injury. PLoS ONE 2015, 10, e0119846. [CrossRef] [PubMed]

55. Ellenbroek, G.H.; van Hout, G.P.; Timmers, L.; Doevendans, P.A.; Pasterkamp, G.; Hoefer, I.E. Primary Outcome Assessment in a Pig Model of Acute Myocardial Infarction. J. Vis. Exp. 2016. [CrossRef] [PubMed]

56. Koudstaal, S.; Jansen of Lorkeers, S.; Gho, J.M.; van Hout, G.P.; Jansen, M.S.; Grundeman, P.F.; Pasterkamp, G.; Doevendans, P.A.; Hoefer, I.E.; Chamuleau, S.A. Myocardial infarction and functional outcome assessment in pigs. J. Vis. Exp. 2014. [CrossRef] [PubMed]

57. Lukovic, D.; Gugerell, A.; Zlabinger, K.; Winkler, J.; Pavo, N.; Baranyai, T.; Giricz, Z.; Varga, Z.V.; Riesenhuber, M.; Spannbauer, A.; et al. Transcriptional Alterations by Ischaemic Postconditioning in a Pig Infarction Model: Impact on Microvascular Protection. Int. J. Mol. Sci. 2019, 20, 344. [CrossRef]

58. Andreadou, I.; Cabrera-Fuentes, H.A.; Devaux, Y.; Frangogiannis, N.G.; Frantz, S.; Guzik, T.; Liehn, E.A.; Gomes, C.P.C.; Schulz, R.; Hausenloy, D.J. Immune cells as targets for cardioprotection: new players and novel therapeutic opportunities. Cardiovasc. Res. 2019, 115, 1117-1130. [CrossRef]

59. Davidson, S.M.; Andreadou, I.; Barile, L.; Birnbaum, Y.; Cabrera-Fuentes, H.A.; Cohen, M.V.; Downey, J.M.; Girao, H.; Pagliaro, P.; Penna, C.; et al. Circulating blood cells and extracellular vesicles in acute cardioprotection. Cardiovasc. Res. 2018, 115, 1156-1166. [CrossRef]

60. Hausenloy, D.J.; Kharbanda, R.K.; Møller, U.K.; Ramlall, M.; Aarøe, J.; Butler, R.; Bulluck, H.; Clayton, T.; Dana, A.; Dodd, M.; et al. Effect of remote ischaemic conditioning on clinical outcomes in patients with acute myocardial infarction (CONDI-2/ERIC-PPCI): a single-blind randomised controlled trial. Lancet 2019. [CrossRef]

61. Schmidt, M.R.; Smerup, M.; Konstantinov, I.E.; Shimizu, M.; Li, J.; Cheung, M.; White, P.A.; Kristiansen, S.B.; Sorensen, K.; Dzavik, V.; et al. Intermittent peripheral tissue ischemia during coronary ischemia reduces myocardial infarction through a KATP-dependent mechanism: First demonstration of remote ischemic perconditioning. Am. J. Physiol. Heart Circ. Physiol. 2007, 292, H1883-H1890. [CrossRef] [PubMed]

62. Ekstrom, K.; Dalsgaard, M.; Iversen, K.; Pedersen-Bjergaard, U.; Vejlstrup, N.; Diemar, S.S.; Idorn, M.; Thorsteinsson, B.; Engstrom, T. Effects of liraglutide and ischemic postconditioning on myocardial salvage after I/R injury in pigs. Scand. Cardiovasc. J. 2017, 51, 8-14. [CrossRef] [PubMed]

63. Schmidt, M.R.; Stottrup, N.B.; Contractor, H.; Hyldebrandt, J.A.; Johannsen, M.; Pedersen, C.M.; Birkler, R.; Ashrafian, H.; Sorensen, K.E.; Kharbanda, R.K.; et al. Remote ischemic preconditioning with-but not without-metabolic support protects the neonatal porcine heart against ischemia-reperfusion injury. Int. J. Cardiol. 2014, 170, 388-393. [CrossRef] [PubMed]

64. Lecour, S. Activation of the protective Survivor Activating Factor Enhancement (SAFE) pathway against reperfusion injury: Does it go beyond the RISK pathway? J. Mol. Cell Cardiol. 2009, 47, 32-40. [CrossRef] [PubMed]

65. Skyschally, A.; Gent, S.; Amanakis, G.; Schulte, C.; Kleinbongard, P.; Heusch, G. Across-Species Transfer of Protection by Remote Ischemic Preconditioning With Species-Specific Myocardial Signal Transduction by Reperfusion Injury Salvage Kinase and Survival Activating Factor Enhancement Pathways. Circ. Res. 2015, 117, 279-288. [CrossRef] [PubMed]

66. Hausenloy, D.J.; Iliodromitis, E.K.; Andreadou, I.; Papalois, A.; Gritsopoulos, G.; Anastasiou-Nana, M.; Kremastinos, D.T.; Yellon, D.M. Investigating the signal transduction pathways underlying remote ischemic conditioning in the porcine heart. Cardiovasc. Drugs Ther. 2012, 26, 87-93. [CrossRef]

67. Pavo, N.; Lukovic, D.; Zlabinger, K.; Zimba, A.; Lorant, D.; Goliasch, G.; Winkler, J.; Pils, D.; Auer, K.; Jan Ankersmit, H.; et al. Sequential activation of different pathway networks in ischemia-affected and non-affected myocardium, inducing intrinsic remote conditioning to prevent left ventricular remodeling. Sci. Rep. 2017, 7, 43958. [CrossRef]

68. Kleinbongard, P.; Skyschally, A.; Gent, S.; Pesch, M.; Heusch, G. STAT3 as a common signal of ischemic conditioning: a lesson on "rigor and reproducibility" in preclinical studies on cardioprotection. Basic. Res. Cardiol. 2018, 113, 3. [CrossRef]

69. Skyschally, A.; Kleinbongard, P.; Lieder, H.; Gedik, N.; Stoian, L.; Amanakis, G.; Elbers, E.; Heusch, G. Humoral transfer and intramyocardial signal transduction of protection by remote ischemic perconditioning in pigs, rats, and mice. Am. J. Physiol. Heart Circ. Physiol. 2018, 315, H159-H172. [CrossRef] 
70. Garcia-Ruiz, J.M.; Galan-Arriola, C.; Fernandez-Jimenez, R.; Aguero, J.; Sanchez-Gonzalez, J.; Garcia-Alvarez, A.; Nuno-Ayala, M.; Dube, G.P.; Zafirelis, Z.; Lopez-Martin, G.J.; et al. Bloodless reperfusion with the oxygen carrier HBOC-201 in acute myocardial infarction: A novel platform for cardioprotective probes delivery. Basic. Res. Cardiol. 2017, 112, 17. [CrossRef]

71. Abdel-Rahman, U.; Risteski, P.; Tizi, K.; Kerscher, S.; Behjati, S.; Zwicker, K.; Scholz, M.; Brandt, U.; Moritz, A. Hypoxic reoxygenation during initial reperfusion attenuates cardiac dysfunction and limits ischemia-reperfusion injury after cardioplegic arrest in a porcine model. J. Thorac. Cardiovasc. Surg. 2009, 137, 978-982. [CrossRef]

72. Jormalainen, M.; Vento, A.E.; Lukkarinen, H.; Kaapa, P.; Kyto, V.; Lauronen, J.; Paavonen, T.; Suojaranta-Ylinen, R.; Petaja, J. Inhibition of thrombin during reperfusion improves immediate postischemic myocardial function and modulates apoptosis in a porcine model of cardiopulmonary bypass. J. Cardiothorac. Vasc. Anesth. 2007, 21, 224-231. [CrossRef] [PubMed]

73. Lavitrano, M.; Smolenski, R.T.; Musumeci, A.; Maccherini, M.; Slominska, E.; Di Florio, E.; Bracco, A.; Mancini, A.; Stassi, G.; Patti, M.; et al. Carbon monoxide improves cardiac energetics and safeguards the heart during reperfusion after cardiopulmonary bypass in pigs. FASEB J. 2004, 18, 1093-1095. [CrossRef] [PubMed]

74. Dworschak, M.; Franz, M.; Hallstrom, S.; Semsroth, S.; Gasser, H.; Haisjackl, M.; Podesser, B.K.; Malinski, T. S-nitroso human serum albumin improves oxygen metabolism during reperfusion after severe myocardial ischemia. Pharmacology 2004, 72, 106-112. [CrossRef] [PubMed]

75. Kupatt, C.; Hinkel, R.; Vachenauer, R.; Horstkotte, J.; Raake, P.; Sandner, T.; Kreuzpointner, R.; Muller, F.; Dimmeler, S.; Feron, O.; et al. VEGF165 transfection decreases postischemic NF-kappa B-dependent myocardial reperfusion injury in vivo: role of eNOS phosphorylation. Faseb. J. 2003, 17, 705-707. [CrossRef] [PubMed]

76. Eiferman, D.; Perez-Tamayo, R.A.; Abe, K.; Okum, E.; Higgins, R. Real-time monitoring of cardiac metabolism using biosensors shows myocardial protection during ischemia-reperfusion injury with glucose-insulin-potassium administration. Surgery 2007, 142, 150-155. [CrossRef] [PubMed]

77. Zhao, Y.T.; Weng, C.L.; Chen, M.L.; Li, K.B.; Ge, Y.G.; Lin, X.M.; Zhao, W.S.; Chen, J.; Zhang, L.; Yin, J.X.; et al. Comparison of glucose-insulin-potassium and insulin-glucose as adjunctive therapy in acute myocardial infarction: A contemporary meta-analysis of randomised controlled trials. Heart 2010, 96, 1622-1626. [CrossRef] [PubMed]

78. Yarbrough, W.M.; Mukherjee, R.; Escobar, G.P.; Mingoia, J.T.; Sample, J.A.; Hendrick, J.W.; Dowdy, K.B.; McLean, J.E.; Stroud, R.E.; Spinale, F.G. Direct inhibition of the sodium/hydrogen exchanger after prolonged regional ischemia improves contractility on reperfusion independent of myocardial viability. J. Thorac. Cardiovasc. Surg. 2003, 126, 1489-1497. [CrossRef]

79. Camara, A.K.; An, J.; Chen, Q.; Novalija, E.; Varadarajan, S.G.; Schelling, P.; Stowe, D.F. Na+/H+ exchange inhibition with cardioplegia reduces cytosolic $[\mathrm{Ca} 2+]$ and myocardial damage after cold ischemia. J. Cardiovasc. Pharm. 2003, 41, 686-698. [CrossRef] [PubMed]

80. Rodriguez-Sinovas, A.; Garcia-Dorado, D.; Padilla, F.; Inserte, J.; Barrabes, J.A.; Ruiz-Meana, M.; Agullo, L.; Soler-Soler, J. Pre-treatment with the $\mathrm{Na}+\mathrm{H}+$ exchange inhibitor cariporide delays cell-to-cell electrical uncoupling during myocardial ischemia. Cardiovasc. Res. 2003, 58, 109-117. [CrossRef]

81. Fedalen, P.A.; Piacentino, V., 3rd; Jeevanandam, V.; Fisher, C.; Greene, J.; Margulies, K.B.; Houser, S.R.; Furukawa, S.; Singhal, A.K.; Goldman, B.I. Pharmacologic pre-conditioning and controlled reperfusion prevent ischemia-reperfusion injury after 30 minutes of hypoxia/ischemia in porcine hearts. J. Heart Lung Transpl. 2003, 22, 1234-1244. [CrossRef]

82. Kupatt, C.; Hinkel, R.; Horstkotte, J.; Deiss, M.; von Bruhl, M.L.; Bilzer, M.; Boekstegers, P. Selective retroinfusion of GSH and cariporide attenuates myocardial ischemia-reperfusion injury in a preclinical pig model. Cardiovasc. Res. 2004, 61, 530-537. [CrossRef] [PubMed]

83. Theroux, P.; Chaitman, B.R.; Danchin, N.; Erhardt, L.; Meinertz, T.; Schroeder, J.S.; Tognoni, G.; White, H.D.; Willerson, J.T.; Jessel, A. Inhibition of the sodium-hydrogen exchanger with cariporide to prevent myocardial infarction in high-risk ischemic situations. Main results of the GUARDIAN trial. Guard during ischemia against necrosis (GUARDIAN) Investigators. Circulation 2000, 102, 3032-3038. [CrossRef] [PubMed] 
84. Weymann, A.; Sabashnikov, A.; Patil, N.P.; Konertz, W.; Modersohn, D.; Dohmen, P.M. Eprosartan improves cardiac function in swine working heart model of ischemia-reperfusion injury. Med. Sci. Monit. Basic Res. 2014, 20, 55-62. [PubMed]

85. Liang, L.N.; Zhong, X.; Zhou, Y.; Hou, Z.Q.; Hu, H.R.; Zhu, F.F.; Chen, J.B.; Ji, X.F.; Shang, D.Y. Cardioprotective effect of nicorandil against myocardial injury following cardiac arrest in swine. Am. J. Emerg. Med. 2017, 35, 1082-1089. [CrossRef] [PubMed]

86. Wang, G.; Zhang, Q.; Yuan, W.; Wu, J.; Li, C. Enalapril protects against myocardial ischemia/reperfusion injury in a swine model of cardiac arrest and resuscitation. Int. J. Mol. Med. 2016, 38, 1463-1473. [CrossRef] [PubMed]

87. Sarja, H.E.; Anttila, T.; Mustonen, C.; Honkanen, H.P.; Herajarvi, J.; Haapanen, H.; Tuominen, H.; Miinalainen, I.; Juvonen, T.; Anttila, V. Diazoxide Attenuates Ischemic Myocardial Injury in a Porcine Model. Heart Surg. Forum 2017, 20, E153-E161. [CrossRef] [PubMed]

88. Hansson, M.J.; Llwyd, O.; Morin, D.; de Paulis, D.; Arnoux, T.; Gouarne, C.; Koul, S.; Engblom, H.; Bordet, T.; Tissier, R.; et al. Differences in the profile of protection afforded by TRO40303 and mild hypothermia in models of cardiac ischemia/reperfusion injury. Eur. J. Pharm. 2015, 760, 7-19. [CrossRef] [PubMed]

89. Atar, D.; Arheden, H.; Berdeaux, A.; Bonnet, J.L.; Carlsson, M.; Clemmensen, P.; Cuvier, V.; Danchin, N.; Dubois-Rande, J.L.; Engblom, H.; et al. Effect of intravenous TRO40303 as an adjunct to primary percutaneous coronary intervention for acute ST-elevation myocardial infarction: MITOCARE study results. Eur. Heart J. 2015, 36, 112-119. [CrossRef]

90. Piot, C.; Croisille, P.; Staat, P.; Thibault, H.; Rioufol, G.; Mewton, N.; Elbelghiti, R.; Cung, T.T.; Bonnefoy, E.; Angoulvant, D.; et al. Effect of Cyclosporine on Reperfusion Injury in Acute Myocardial Infarction. N. Engl. J. Med. 2008, 359, 473-481. [CrossRef]

91. Cung, T.-T.; Morel, O.; Cayla, G.; Rioufol, G.; Garcia-Dorado, D.; Angoulvant, D.; Bonnefoy-Cudraz, E.; Guérin, P.; Elbaz, M.; Delarche, N.; et al. Cyclosporine before PCI in Patients with Acute Myocardial Infarction. N. Engl. J. Med. 2015, 373, 1021-1031. [CrossRef] [PubMed]

92. Karlsson, L.O.; Zhou, A.X.; Larsson, E.; Astrom-Olsson, K.; Mansson, C.; Akyurek, L.M.; Grip, L. Cyclosporine does not reduce myocardial infarct size in a porcine ischemia-reperfusion model. J. Cardiovasc. Pharm. 2010, 15, 182-189. [CrossRef] [PubMed]

93. Malka, A.; Meerkin, D.; Barac, Y.D.; Malits, E.; Bachner-Hinenzon, N.; Carasso, S.; Ertracht, O.; Angel, I.; Shofti, R.; Youdim, M.; et al. TVP1022: A Novel Cardioprotective Drug Attenuates Left Ventricular Remodeling After Ischemia/Reperfusion in Pigs. J. Cardiovasc. Pharm. 2015, 66, 214-222. [CrossRef] [PubMed]

94. Rayner, B.S.; Figtree, G.A.; Sabaretnam, T.; Shang, P.; Mazhar, J.; Weaver, J.C.; Lay, W.N.; Witting, P.K.; Hunyor, S.N.; Grieve, S.M.; et al. Selective inhibition of the master regulator transcription factor Egr-1 with catalytic oligonucleotides reduces myocardial injury and improves left ventricular systolic function in a preclinical model of myocardial infarction. J. Am. Heart Assoc. 2013, 2, e000023. [CrossRef] [PubMed]

95. Heusch, G.; Kleinbongard, P. Ivabradine: Cardioprotection By and Beyond Heart Rate Reduction. Drugs 2016, 76, 733-740. [CrossRef] [PubMed]

96. Priti, K.; Ranwa, B.L.; Gokhroo, R.K.; Kishore, K.; Bisht, D.S.; Gupta, S. Ivabradine vs metoprolol in patients with acute inferior wall myocardial infarction- “Expanding arena for ivabradine”. Cardiovasc. Ther. 2017, 35, e12266. [CrossRef] [PubMed]

97. Hesen, N.A.; Riksen, N.P.; Aalders, B.; Brouwer, M.A.; Ritskes-Hoitinga, M.; El Messaoudi, S.; Wever, K.E. A systematic review and meta-analysis of the protective effects of metformin in experimental myocardial infarction. PLoS ONE 2017, 12, e0183664. [CrossRef] [PubMed]

98. Lu, L.; Ye, S.; Scalzo, R.L.; Reusch, J.E.B.; Greyson, C.R.; Schwartz, G.G. Metformin prevents ischaemic ventricular fibrillation in metabolically normal pigs. Diabetologia 2017, 60, 1550-1558. [CrossRef] [PubMed]

99. Suzuki, T.; Saiki, Y.; Horii, A.; Fukushige, S.; Kawamoto, S.; Adachi, O.; Akiyama, M.; Ito, K.; Masaki, N.; Saiki, Y. Atrial natriuretic peptide induces peroxisome proliferator activated receptor gamma during cardiac ischemia-reperfusion in swine heart. Gen. Thorac. Cardiovasc. Surg. 2017, 65, 85-95. [CrossRef]

100. Lassaletta, A.D.; Elmadhun, N.Y.; Zanetti, A.V.; Feng, J.; Anduaga, J.; Gohh, R.Y.; Sellke, F.W.; Bianchi, C. Rapamycin treatment of healthy pigs subjected to acute myocardial ischemia-reperfusion injury attenuates cardiac functions and increases myocardial necrosis. Ann. Thorac. Surg. 2014, 97, 901-907. [CrossRef] 
101. Seewald, M.; Coles, J.A., Jr.; Sigg, D.C.; Iaizzo, P.A. Featured Article: Pharmacological postconditioning with delta opioid attenuates myocardial reperfusion injury in isolated porcine hearts. Exp. Biol. Med. (Maywood) 2017, 242, 986-995. [CrossRef] [PubMed]

102. Swartz, M.F.; Halter, J.M.; Fink, G.W.; Pavone, L.; Zaitsev, A.; Lee, H.M.; Steinberg, J.M.; Lutz, C.J.; Sorsa, T.; Gatto, L.A.; et al. Chemically modified tetracycline improves contractility in porcine coronary ischemia/reperfusion injury. J. Card. Surg. 2006, 21, 254-260. [CrossRef] [PubMed]

103. Sodha, N.R.; Clements, R.T.; Feng, J.; Liu, Y.; Bianchi, C.; Horvath, E.M.; Szabo, C.; Stahl, G.L.; Sellke, F.W. Hydrogen sulfide therapy attenuates the inflammatory response in a porcine model of myocardial ischemia/reperfusion injury. J. Thorac. Cardiovasc. Surg. 2009, 138, 977-984. [CrossRef] [PubMed]

104. Arslan, F.; Houtgraaf, J.H.; Keogh, B.; Kazemi, K.; de Jong, R.; McCormack, W.J.; O’Neill, L.A.; McGuirk, P.; Timmers, L.; Smeets, M.B.; et al. Treatment with OPN-305, a humanized anti-Toll-Like receptor-2 antibody, reduces myocardial ischemia/reperfusion injury in pigs. Circ. Cardiovasc. Interv. 2012, 5, 279-287. [CrossRef] [PubMed]

105. Palee, S.; Weerateerangkul, P.; Surinkeaw, S.; Chattipakorn, S.; Chattipakorn, N. Effect of rosiglitazone on cardiac electrophysiology, infarct size and mitochondrial function in ischaemia and reperfusion of swine and rat heart. Exp. Physiol. 2011, 96, 778-789. [CrossRef] [PubMed]

106. Roberts, R.; DeMello, V.; Sobel, B.E. Deleterious effects of methylprednisolone in patients with myocardial infarction. Circulation 1976, 53, 204-206.

107. Huang, S.; Frangogiannis, N.G. Anti-inflammatory therapies in myocardial infarction: failures, hopes and challenges. Br. J. Pharmacol. 2018, 175, 1377-1400. [CrossRef]

108. Kupatt, C.; Wichels, R.; Deiss, M.; Molnar, A.; Lebherz, C.; Raake, P.; von Degenfeld, G.; Hahnel, D.; Boekstegers, P. Retroinfusion of NFkappaB decoy oligonucleotide extends cardioprotection achieved by CD18 inhibition in a preclinical study of myocardial ischemia and retroinfusion in pigs. Gene Ther. 2002, 9, 518-526.

109. Van Hout, G.P.; Bosch, L.; Ellenbroek, G.H.; de Haan, J.J.; van Solinge, W.W.; Cooper, M.A.; Arslan, F.; de Jager, S.C.; Robertson, A.A.; Pasterkamp, G.; et al. The selective NLRP3-inflammasome inhibitor MCC950 reduces infarct size and preserves cardiac function in a pig model of myocardial infarction. Eur. Heart J. 2017, 38, 828-836. [CrossRef]

110. Hinkel, R.; Lange, P.; Petersen, B.; Gottlieb, E.; Ng, J.K.; Finger, S.; Horstkotte, J.; Lee, S.; Thormann, M.; Knorr, M.; et al. Heme Oxygenase-1 Gene Therapy Provides Cardioprotection Via Control of Post-Ischemic Inflammation: An Experimental Study in a Pre-Clinical Pig Model. J. Am. Coll. Cardiol. 2015, 66, 154-165. [CrossRef]

111. Hinkel, R.; Trenkwalder, T.; Petersen, B.; Husada, W.; Gesenhues, F.; Lee, S.; Hannappel, E.; Bock-Marquette, I.; Theisen, D.; Leitner, L.; et al. MRTF-A controls vessel growth and maturation by increasing the expression of CCN1 and CCN2. Nat. Commun. 2014, 5, 3970. [CrossRef] [PubMed]

112. Dorn, T.; Kornherr, J.; Parrotta, E.I.; Zawada, D.; Ayetey, H.; Santamaria, G.; Iop, L.; Mastantuono, E.; Sinnecker, D.; Goedel, A.; et al. Interplay of cell-cell contacts and RhoA/MRTF-A signaling regulates cardiomyocyte identity. EMBO J. 2018, 37. [CrossRef] [PubMed]

113. Ziegler, T.; Hinkel, R.; Stöhr, A.; Eschenhagen, T.; Laugwitz, K.-L.; le Noble, F.; David, R.; Hansen, A.; Kupatt, C. Thymosinß4 Improves Differentiation and Vascularization of EHTs. Stem Cells Int. 2017, $2017,10$. [CrossRef] [PubMed]

114. Hinkel, R.; El-Aouni, C.; Olson, T.; Horstkotte, J.; Mayer, S.; Muller, S.; Willhauck, M.; Spitzweg, C.; Gildehaus, F.J.; Munzing, W.; et al. Thymosin beta4 is an essential paracrine factor of embryonic endothelial progenitor cell-mediated cardioprotection. Circulation 2008, 117, 2232-2240. [CrossRef] [PubMed]

115. Sun, L.; Hao, Y.; Nie, X.; Xu, J.; Li, Z.; Zhang, W.; Liu, Y.; Zhang, X. Recombinant AAV-PR39-mediated hypoxia-inducible factor 1alpha gene expression attenuates myocardial infarction. Int. J. Mol. Med. 2014, 33, 171-177. [CrossRef] [PubMed]

116. Hullinger, T.G.; Montgomery, R.L.; Seto, A.G.; Dickinson, B.A.; Semus, H.M.; Lynch, J.M.; Dalby, C.M.; Robinson, K.; Stack, C.; Latimer, P.A.; et al. Inhibition of miR-15 protects against cardiac ischemic injury. Circ. Res. 2012, 110, 71-81. [CrossRef] [PubMed]

117. Hinkel, R.; Penzkofer, D.; Zuehlke, S.; Fischer, A.; Husada, W.; Xu, Q.F.; Baloch, E.; van Rooij, E.; Zeiher, A.M.; Kupatt, C.; et al. Inhibition of MicroRNA-92a Protects Against Ischemia-Reperfusion Injury in a Large Animal Model. Circulation 2013, 128, 1066-1075. [CrossRef] [PubMed] 
118. Lemckert, F.A.; Bournazos, A.; Eckert, D.M.; Kenzler, M.; Hawkes, J.M.; Butler, T.L.; Ceely, B.; North, K.N.; Winlaw, D.S.; Egan, J.R.; et al. Lack of MG53 in human heart precludes utility as a biomarker of myocardial injury or endogenous cardioprotective factor. Cardiovasc. Res. 2016, 110, 178-187. [CrossRef]

119. Zhou, X.; Chen, M.; Wang, S.; Yu, L.; Jiang, H. MG53 protein: A promising novel therapeutic target for myocardial ischemia reperfusion injury. Int. J. Cardiol. 2015, 199, 424-425. [CrossRef]

120. Liu, J.; Zhu, H.; Zheng, Y.; Xu, Z.; Li, L.; Tan, T.; Park, K.H.; Hou, J.; Zhang, C.; Li, D.; et al. Cardioprotection of recombinant human MG53 protein in a porcine model of ischemia and reperfusion injury. J. Mol. Cell Cardiol. 2015, 80, 10-19. [CrossRef]

121. Drevinge, C.; Karlsson, L.O.; Stahlman, M.; Larsson, T.; Perman Sundelin, J.; Grip, L.; Andersson, L.; Boren, J.; Levin, M.C. Cholesteryl esters accumulate in the heart in a porcine model of ischemia and reperfusion. PLoS ONE 2013, 8, e61942. [CrossRef] [PubMed]

122. Pedersen, C.M.; Venkatasubramanian, S.; Vase, H.; Hyldebrandt, J.A.; Contractor, H.; Schmidt, M.R.; Botker, H.E.; Cruden, N.L.; Newby, D.E.; Kharbanda, R.K.; et al. Rotigaptide protects the myocardium and arterial vasculature from ischaemia reperfusion injury. Br. J. Clin. Pharm. 2016, 81, 1037-1045. [CrossRef] [PubMed]

123. Sheriff, A.; Schindler, R.; Vogt, B.; Abdel-Aty, H.; Unger, J.K.; Bock, C.; Gebauer, F.; Slagman, A.; Jerichow, T.; Mans, D.; et al. Selective apheresis of C-reactive protein: a new therapeutic option in myocardial infarction? J. Clin. Apher. 2015, 30, 15-21. [CrossRef] [PubMed]

124. Bergmark, B.A.; Bhatt, D.L.; McGuire, D.K.; Cahn, A.; Mosenzon, O.; Steg, P.G.; Im, K.; Kanevsky, E.; Gurmu, Y.; Raz, I.; et al. Metformin Use and Clinical Outcomes among Patients with Diabetes with or without Heart Failure or Kidney Dysfunction: Observations from the SAVOR-TIMI 53 Trial. Circulation 2019, 140, 1004-1014. [CrossRef] [PubMed]

125. Jeyaraman, M.M.; Rabbani, R.; Copstein, L.; Sulaiman, W.; Farshidfar, F.; Kashani, H.H.; Qadar, S.M.Z.; Guan, Q.; Skidmore, B.; Kardami, E.; et al. Autologous Bone Marrow Stem Cell Therapy in Patients With ST-Elevation Myocardial Infarction: A Systematic Review and Meta-analysis. Can. J. Cardiol. 2017, 33, 1611-1623. [CrossRef] [PubMed]

126. Yanamandala, M.; Zhu, W.; Garry, D.J.; Kamp, T.J.; Hare, J.M.; Jun, H.W.; Yoon, Y.S.; Bursac, N.; Prabhu, S.D.; Dorn, G.W.; et al. Overcoming the Roadblocks to Cardiac Cell Therapy Using Tissue Engineering. J. Am. Coll. Cardiol. 2017, 70, 766-775. [CrossRef]

127. Sharp, T.E.; Schena, G.J.; Hobby, A.R.; Starosta, T.; Berretta, R.M.; Wallner, M.; Borghetti, G.; Gross, P.; Yu, D.; Johnson, J.; et al. Cortical Bone Stem Cell Therapy Preserves Cardiac Structure and Function After Myocardial Infarction. Circ. Res. 2017, 121, 1263-1278. [CrossRef]

128. Cai, M.; Shen, R.; Song, L.; Lu, M.; Wang, J.; Zhao, S.; Tang, Y.; Meng, X.; Li, Z.; He, Z.X. Bone Marrow Mesenchymal Stem Cells (BM-MSCs) Improve Heart Function in Swine Myocardial Infarction Model through Paracrine Effects. Sci. Rep. 2016, 6, 28250. [CrossRef]

129. Kanazawa, H.; Tseliou, E.; Malliaras, K.; Yee, K.; Dawkins, J.F.; De Couto, G.; Smith, R.R.; Kreke, M.; Seinfeld, J.; Middleton, R.C.; et al. Cellular postconditioning: Allogeneic cardiosphere-derived cells reduce infarct size and attenuate microvascular obstruction when administered after reperfusion in pigs with acute myocardial infarction. Circ. Heart Fail. 2015, 8, 322-332. [CrossRef]

130. Kanazawa, H.; Tseliou, E.; Dawkins, J.F.; De Couto, G.; Gallet, R.; Malliaras, K.; Yee, K.; Kreke, M.; Valle, I.; Smith, R.R.; et al. Durable Benefits of Cellular Postconditioning: Long-Term Effects of Allogeneic Cardiosphere-Derived Cells Infused After Reperfusion in Pigs with Acute Myocardial Infarction. J. Am. Heart Assoc 2016, 5. [CrossRef]

131. Gallet, R.; Tseliou, E.; Dawkins, J.; Middleton, R.; Valle, J.; Angert, D.; Reich, H.; Luthringer, D.; Kreke, M.; Smith, R.; et al. Intracoronary delivery of self-assembling heart-derived microtissues (cardiospheres) for prevention of adverse remodeling in a pig model of convalescent myocardial infarction. Circ. Cardiovasc. Interv. 2015, 8. [CrossRef] [PubMed]

132. Collantes, M.; Pelacho, B.; Garcia-Velloso, M.J.; Gavira, J.J.; Abizanda, G.; Palacios, I.; Rodriguez-Borlado, L.; Alvarez, V.; Prieto, E.; Ecay, M.; et al. Non-invasive in vivo imaging of cardiac stem/progenitor cell biodistribution and retention after intracoronary and intramyocardial delivery in a swine model of chronic ischemia reperfusion injury. J. Transl. Med. 2017, 15, 56. [CrossRef] [PubMed] 
133. Bolli, R.; Chugh, A.R.; D'Amario, D.; Loughran, J.H.; Stoddard, M.F.; Ikram, S.; Beache, G.M.; Wagner, S.G.; Leri, A.; Hosoda, T.; et al. Cardiac stem cells in patients with ischaemic cardiomyopathy (SCIPIO): Initial results of a randomised phase 1 trial. Lancet 2011, 378, 1847-1857. [CrossRef]

134. Malliaras, K.; Makkar, R.R.; Smith, R.R.; Cheng, K.; Wu, E.; Bonow, R.O.; Marbán, L.; Mendizabal, A.; Cingolani, E.; Johnston, P.V.; et al. Intracoronary Cardiosphere-Derived Cells After Myocardial Infarction: Evidence of Therapeutic Regeneration in the Final 1-Year Results of the CADUCEUS Trial (CArdiosphere-Derived aUtologous stem CElls to reverse ventricUlar dySfunction). J. Am. Coll. Cardiol. 2014, 63, 110-122. [CrossRef] [PubMed]

135. Sahoo, S.; Losordo, D.W. Exosomes and Cardiac Repair After Myocardial Infarction. Circ. Res. 2014, 114, 333-344. [CrossRef] [PubMed]

136. Gallet, R.; Dawkins, J.; Valle, J.; Simsolo, E.; de Couto, G.; Middleton, R.; Tseliou, E.; Luthringer, D.; Kreke, M.; Smith, R.R.; et al. Exosomes secreted by cardiosphere-derived cells reduce scarring, attenuate adverse remodelling, and improve function in acute and chronic porcine myocardial infarction. Eur. Heart J. 2017, 38, 201-211. [CrossRef]

137. De Couto, G.; Gallet, R.; Cambier, L.; Jaghatspanyan, E.; Makkar, N.; Dawkins, J.F.; Berman, B.P.; Marban, E. Exosomal MicroRNA Transfer Into Macrophages Mediates Cellular Postconditioning. Circulation 2017, 136, 200-214. [CrossRef]

138. Seif-Naraghi, S.B.; Singelyn, J.M.; Salvatore, M.A.; Osborn, K.G.; Wang, J.J.; Sampat, U.; Kwan, O.L.; Strachan, G.M.; Wong, J.; Schup-Magoffin, P.J.; et al. Safety and efficacy of an injectable extracellular matrix hydrogel for treating myocardial infarction. Sci. Transl. Med. 2013, 5, 173ra25. [CrossRef]

139. Rao, S.V.; Zeymer, U.; Douglas, P.S.; Al-Khalidi, H.; White, J.A.; Liu, J.; Levy, H.; Guetta, V.; Gibson, C.M.; Tanguay, J.-F.; et al. Bioabsorbable Intracoronary Matrix for Prevention of Ventricular Remodeling After Myocardial Infarction. J. Am. Coll. Cardiol. 2016, 68, 715-723. [CrossRef]

140. Bassat, E.; Mutlak, Y.E.; Genzelinakh, A.; Shadrin, I.Y.; Baruch-Umansky, K.; Yifa, O.; Kain, D.; Rajchman, D.; Leach, J.; Bassat, D.R.; et al. The extracellular matrix protein Agrin promotes heart regeneration in mice. Nature 2017, 347, 179-184. [CrossRef]

141. Romagnuolo, R.; Masoudpour, H.; Porta-Sánchez, A.; Qiang, B.; Barry, J.; Laskary, A.; Qi, X.; Massé, S.; Magtibay, K.; Kawajiri, H.; et al. Human Embryonic Stem Cell-Derived Cardiomyocytes Regenerate the Infarcted Pig Heart but Induce Ventricular Tachyarrhythmias. Stem Cell Rep. 2019, 12, 967-981. [CrossRef] [PubMed]

142. Weinberger, F.; Breckwoldt, K.; Pecha, S.; Kelly, A.; Geertz, B.; Starbatty, J.; Yorgan, T.; Cheng, K.-H.; Lessmann, K.; Stolen, T.; et al. Cardiac repair in guinea pigs with human engineered heart tissue from induced pluripotent stem cells. Sci. Transl. Med. 2016, 8, 363ra148. [CrossRef] [PubMed]

143. Pecha, S.; Yorgan, K.; Rohl, M.; Geertz, B.; Hansen, A.; Weinberger, F.; Sehner, S.; Ehmke, H.; Reichenspurner, H.; Eschenhagen, T.; et al. Human iPS cell-derived engineered heart tissue does not affect ventricular arrhythmias in a guinea pig cryo-injury model. Sci. Rep. 2019, 9, 9831. [CrossRef] [PubMed]

144. Boettcher, A.N.; Loving, C.L.; Cunnick, J.E.; Tuggle, C.K. Development of Severe Combined Immunodeficient (SCID) Pig Models for Translational Cancer Modeling: Future Insights on How Humanized SCID Pigs Can Improve Preclinical Cancer Research. Front. Oncol. 2018, 8, 559. [CrossRef] [PubMed]

145. Powell, E.J.; Charley, S.; Boettcher, A.N.; Varley, L.; Brown, J.; Schroyen, M.; Adur, M.K.; Dekkers, S.; Isaacson, D.; Sauer, M.; et al. Creating effective biocontainment facilities and maintenance protocols for raising specific pathogen-free, severe combined immunodeficient (SCID) pigs. Lab. Anim. 2018, 52, 402-412. [CrossRef]

146. Bahr, A.; Kaser, T.; Kemter, E.; Gerner, W.; Kurome, M.; Baars, W.; Herbach, N.; Witter, K.; Wunsch, A.; Talker, S.C.; et al. Ubiquitous LEA29Y Expression Blocks T Cell Co-Stimulation but Permits Sexual Reproduction in Genetically Modified Pigs. PLoS ONE 2016, 11, e0155676. [CrossRef] [PubMed]

147. Egerer, S.; Fiebig, U.; Kessler, B.; Zakhartchenko, V.; Kurome, M.; Reichart, B.; Kupatt, C.; Klymiuk, N.; Wolf, E.; Denner, J.; et al. Early weaning completely eliminates porcine cytomegalovirus from a newly established pig donor facility for xenotransplantation. Xenotransplantation 2018, 25, e12449. [CrossRef]

148. Rossello, X.; Yellon, D.M. Cardioprotection: The Disconnect Between Bench and Bedside. Circulation 2016, 134, 574-575. [CrossRef]

149. Heusch, G. Critical Issues for the Translation of Cardioprotection. Circ. Res. 2017, 120, 1477-1486. [CrossRef] 
150. Sorop, O.; Heinonen, I.; van Kranenburg, M.; van de Wouw, J.; de Beer, V.J.; Nguyen, I.T.N.; Octavia, Y.; van Duin, R.W.B.; Stam, K.; van Geuns, R.J.; et al. Multiple common comorbidities produce left ventricular diastolic dysfunction associated with coronary microvascular dysfunction, oxidative stress, and myocardial stiffening. Cardiovasc. Res. 2018, 114, 954-964. [CrossRef]

151. Mendieta, G.; Ben-Aicha, S.; Gutierrez, M.; Casani, L.; Arzanauskaite, M.; Carreras, F.; Sabate, M.; Badimon, L.; Vilahur, G. Intravenous statin administration during MI enhances cardioprotection and improves post-MI healing compared to oral administration. J. Am. Coll. Cardiol. 2019, in press.

(C) 2019 by the authors. Licensee MDPI, Basel, Switzerland. This article is an open access article distributed under the terms and conditions of the Creative Commons Attribution (CC BY) license (http://creativecommons.org/licenses/by/4.0/). 